\title{
Jurist-Diction
}

Volume 3 No. 5, September 2020

\section{Pertimbangan Hakim Memutus Lebih Ringan Terhadap Perkara Pecandu Narkotika}

\author{
Dio Aliefs Taufan \\ Dioaliefs23@gmail.com \\ Universitas Airlangga
}

How to cite:

Dio Aliefs Taufan,

'Pertimbangan Hakim

Memutus Lebih Ringan

Terhadap Perkara Pecandu

Narkotika' (2020) Vol. 3 No. 5

Jurist-Diction.

Histori artikel:

Submit 21 Juli 2020;

Diterima 14 Agustus 2020;

Diterbitkan 1 September 2020.

DOI:

10.20473/jd.v3i5.21970

\begin{abstract}
Abstrak
Artikel ini bertujuan untuk menganalisis putusan hakim dalam memberikan putusan pada perkara tindak pidana narkotika yang UU Narkotika menganut double track system, yaitu menerapkan sanksi pidana penjara dan tindakan rehabilitasi. Ketidakadilan dalam penanganan perkara narkotika, khususnya terhadap pecandu narkotika yang seharusnya dijatuhkan tindakan rehabilitasi namun jaksa penuntut umum dan hakim memutuskan penyalahguna narkotika harus dipidana penjara. Tipe penelitian skripsi adalah penelitian hukum normatif, dengan pendekatan perundang undangan, pendekatan konsep dan pendekatan kasus. Kualifikasi pecandu berbeda dengan penyalahguna narkotika. Pecandu Narkotika yaitu :1. Orang yang menggunakan Narkotika dalam keadaaan ketergantungan secara fisik maupun psikis, dan 2.Orang yang menyalahgunakan narkotika dalam keadaan ketergantungan secara fisik maupun psikis. Sedangkan pengertian penyalahguna adalah orang yang menggunakan Narkotika tanpa hak atau melawan hukum. UU Narkotika merupakan sebuah aturan hukum yang dijadikan dasar pertimbangan hukum hakim dalam memutus lebih ringan terhadap pecandu narkotika. Berdasarkan putusan hakim, pertimbangan memutus lebih ringan pecandu narkotika karena, seorang pecandu bukanlah seorang pelaku tindak pidana, pecandu adalah seorang korban yang perlu disembuhkan. Seorang pengguna narkotika merupakan pelaku tindak pidana sekaligus sebagai korban penyalahgunaan narkotika. Seorang pelaku tindak pidana penyalahgunaan narkotika diminta melakukan Visum Et Repertum akan berubah status menjadi pecandu dan hukumnya wajib direhabilitasi. sesungguhnya Penyalahguna Narkotika telah merugikan dirinya sendiri sehingga dapat pula dikategorikan sebagai korban ataupun sebagai pelaku dari tindak pidana penyalahgunaan narkotika.
\end{abstract}

Kata Kunci: Double Track System; Rehabilitasi;Visum Et Repertum.

\section{Pendahuluan}

Pengaruh narkotika tidak hanya berdampak pada fisik dan psikis pengguna, namun juga berpengaruh pada kehidupan sosial, ekonomi, masyarakat, bahkan terhadap negara. Masalah yang dapat ditimbulkan akibat adanya penyalahgunaan narkotika yaitu seperti gagal dalam pendidikan, pekerjaan ataupun dalam bekeluarga, 
dapat menimbulkan tingkat kriminalitas yang tinggi, dapat meningkatkan seks bebas yang juga dapat mengakibatkan terjangkitnya penyakit HIV/AIDS yang dapat berujung pada kematian.

Berdasarkkan data Badan Narkotika Nasional (BNN), umlah penyalahgunaan narkotika di Indonesia cenderung meningkat dari tahun ke tahun. BNN mencatat jumlah penyalahguna (pecandu) narkotika, sebagaimana digambarkan dalam table berikut ini:

Menurut data survey prevalensi penyalahgunaan Narkoba tahun 2008-2017 yang dilaksanakan oleh BNN menunjukkan bahwa angka prevalensi penyalahgunaan narkoba di Indonesia berada di kisaran angka 1,7 - 2,2\% atau sekitar 3-5 juta jiwa. Angka tersebut merupakan batas kritis yang harus dikendalikan dan ditekan agar tidak semakin meningkat.

Kepala BNN Komjen. Pol. Drs. Gories Mere menyebutkan pada semester pertama 2011 kejahatan Narkoba meningkat hingga $67 \%$. Berdasarkan hasil survei BNN bekerja sama dengan Pusat Penelitian Kesehatan Universitas Indonesia pada tahun 2008 terdapat sekitar 3,6 juta orang penyalahguna narkoba di Indonesia. Bila tidak dilakukan penangangan serius maka diperkirakan pada tahun 2015 jumlah penyalahguna narkoba akan meningkat menjadi 5,1 juta jiwa. ${ }^{1}$

Tindak pidana yang menyangkut narkotika merupakan tindak pidana khusus yang menyebar secara nasional maupun internasional, karena penyalahgunaan narkotika dapat menimbulkan dampak negatif dalam kehidupan masyarakat, bangsa dan negara. Bentuk tindak pidana narkotika yang umum dikenal adalah: 1.Penyalahgunaan melebihi dosis; 2. Pengedaran; dan 3. jual beli narkotika. ${ }^{2}$

Menurut Pasal 5 ayat (1) UU Narkotika terdapat 3 (tiga) golongan Narkotika, yaitu: A. Narkotika golongan I

Narkotika ini hanya digunakan untuk tujuan ilmu pengetahuan dan tidak digunakan dalam terapi/pengobatan serta memiliki potensi tinggi untuk mengakibatkan sindrom ketergantungan.

\footnotetext{
1 NN, 'Sinar edisi'<www.HukumOnline.com >, accessed 8 September 2011.

2 Mohammad Taufik Makarao, Suhasril, Risman F Sikumbank, Tindak Pidana Narkotika (Ghalia Indonesia 2003).[45].
} 
B. Narkotika golongan II

Narkotika ini untuk pengobatan yang digunakan sebagai pilihan terakhir dan dapat digunakan dalam terapi/pengobatan atau untuk tujuan ilmu pengetahuan serta memiliki potensi kuat untuk mengakibatkan sindrom ketergantungan.

C. Narkotika golongan III

Narkotika ini untuk pengobatan dan banyak digunakan dalam terapi/pengobatan atau untuk tujuan ilmu yang pengetahuan serta berpotensi ringan mengakibatkan sindrom ketergantungan.

Penyalahgunaan narkotika juga dapat berpengaruh pada kualitas sumber daya manusia dan terhadap masa depan bangsa, karena korban yang terdampak dari penyalahgunaan narkotika adalah generasi muda. Dapat kita lihat pada pembukaan Undang - Undang Dasar 1945 tercantum dalam tujuan negara yaitu generasi muda adalah elemen penting untuk mencapai cita-cita pembangunan nasional.

Menurut Gatot Supramono, menyatakan bahwa narkotika dapat menjadi penghambat pembangunan nasional yang beraspek materiel-spiritual. Bahaya pemakaian narkotika sangat berpengaruh besar terhadap negara jika pemakaian narkotika secara besar-besaran di masyarakat dapat mengakibatkan bangsa Indonesia menjadi bangsa yang sakit,apabila terjadi demikian negara akan rapuh dari dalam karena ketahanan nasional akan menurun. ${ }^{3}$ Dalam hal mengatur serta mencegah semakin meluasnya dampak penyalahgunaan narkotika tersebut, keberadaan hukum pidana sangat diperlukan. Hukum pidana sebagai hukum publik yang mengatur mengenai hubungan hukum antara negara dengan warga negara memuat sejumlah norma dan ketentuan yang harus ditaati yang bertujuan agar terciptanya keselarasan, kepastian dan ketertiban hukum dalam kehidupan berbangsa dan bernegara.

Penegakan hukum itu sendiri merupakan upaya penanggulangan kejahatan melalui cara-cara yang rasional. Maksudnya, agar adanya kesesuaian antara apa yang diinginkan dari adanya suatu peraturan atau cita - cita normatif dalam undang-undang (das sollen) dengan kenyataan peristiwa yang terjadi di masyarakat

3 Gatot Supramono, Hukum Narkoba Indonesia (Djambatan 2004).[5]. 
(das sein). Barda Nawawi Arief mengatakan bahwa, penegakan hukum tidak lain sebagai suatu upaya untuk mewujudkan atau menerapkan ketentuan hukum kedalam peristiwa - peristiwa yang nyata. ${ }^{4}$

Muladi mengemukakan bahwa penegakan hukum jika dilihat dari suatu proses kebijakan, maka penegakan hukum pada hakekatnya merupakan penegakan kebijakan melalui beberapa tahap, yaitu :

1. Tahap Formulasi, adalah tahap penegakan hukum pidana in abstracto oleh badan pembentuk undang-undang. Dalam tahap ini pembentuk undangundang melakukan kegiatan memilih nilai-nilai yang sesuai dengan keadaan dan situasi masa kini dan masa yang akan datang, kemudian merumuskannya dalam bentuk peraturan perundang-undangan yang paling baik, dalam arti memenuhi syarat keadilan dan daya guna. Tahap ini dapat juga disebut dengan tahap kebijakan legislatif.

2. Tahap Aplikasi, adalah tahap penegakan hukum pidana (tahap penerapan hukum pidana) oleh aparat-aparat mulai dari kepolisian, kejaksaan hingga pengadilan. Dalam tahap ini aparat penegak hukum menegakkan serta menerapkan peraturan perundang - undangan pidana yang telah dibuat oleh badan pembentuk undang undang. Dalam melaksanakan tugas ini, aparat penegak hukum harus memegang teguh nilai - nilai keadilan dan daya guna. Tahap yang kedua ini dapat juga disebut sebagai tahap kebijakan yudikatif.

3. Tahap Eksekusi, yaitu tahap penegakan (pelaksanaan) hukum pidana secara konkret oleh aparat pelaksana pidana. Dalam tahap ini aparat pelaksana pidana bertugas menegakkan peraturan pidana yang telah dibuat oleh pembentu undangundang melalui penerapan pidana yang telah ditetapkan oleh pengadilan. Aparat pelaksana dalam menjalankan tugasnya harus berpedoman kepada peraturan perundang-undangan pidana yang telah dibuat oleh pembentuk undang-undang (legislator) dan nilai-nilai keadilan serta daya guna. ${ }^{5}$

\footnotetext{
${ }^{4}$ Barda Nawawi Arief, Beberapa Aspek Kebijakan Penegakan dan Pengembangan Hukum Pidana (Citra Aditya Bakti 1998).[22].

5 Muladi, Kapita Selekta Sistem Peradilan Pidana (Badan Penerbit Universitas Diponegoro 1995).[13-14].
} 
Penyalahgunaan narkotika dikategorikan sebagai tindak pidana karena akibat yang ditimbulkan sangat berbahaya. Ketentuan perundang-undangan yang mengatur tentang masalah narkotika telah diberlakukan, namun kejahatan menyangkut narkotika sampai saat ini tidak dapat diredakan. Adanya pemidanaan dengan kasus narkotika bukanlah satu-satunya pemberian hukuman terhadap orang yang telah melakukan tindak pidana tetapi juga merestorasi keadilan terhadap korban. Aspek pemidanaan yang diberikan terhadap pecandu narkotika ditunjukkan untuk memberikan perawatan (treatment) dan perbaikan (rehabilitation) daripada hanya sekedar penghukuman.

Upaya yang dilakukan untuk mengurangi tindak kejahatan penyalahgunaan narkotika tidak terlepas dari peranan hakim sebagai salah satu aparat penegak hukum yang tugasnya mengadili tersangka/terdakwa. Keputusan hakim dalam mengambil suatu keputusan harus mempunyai pertimbangan yang bijak agar putusan tersebut bedasarkan asas keadilan. Hakim memiliki kebebasan untuk menentukan jenis pidana dan tinggi rendahnya pidana, dan hakim juga mempunyai kebebasan untuk bergerak pada batas minimum dan maksimum sanksi pidana yang diatur dalam undang - undang untuk tiap tindak pidana. Hal ini dapat menunjukkan bahwa masalah pemidanaan sepenuhnya merupakan kekuasaan hakim. ${ }^{6}$

Seperti yang telah dijelaskan diatas penyalahgunaan narkotika merupakan suatu kejahatan karena menggunakan narkotika tanpa hak atau melawan hukum dan digunakan dalam hal yang negatif maka lama-lama orang akan jadi kecanduan (adiksi), tidak mau lepas dari rasa nikmat itu meski jiwanya terancam sekalipun. Dalam kasus penyalahgunaan narkotika ini apakah akan diterapkan sanksi pidana atau sanksi tindakan penentuannya semua ada ditangan hakim. Karena dalam UU Narkotika memberikan kewenangan terhadap hakim untuk menjatuhkan pidana penjara atau tindakan rehabilitasi bagi pecandu narkotika. Keberadaan hakim yang bebas dan tidak memihak dalam proses peradilan pidana sangat menentukan wujudnya tujuan sistem peradilan pidana. Hakim yang bebas dan tidak memihak

\footnotetext{
6 Sudarto, Kapita Selekta Hukum Pidana (Alumni 1986).[78].
} 
telah menjadi ketentuan universal dan menjadi negara hukum. ${ }^{7}$

\section{Kualifikasi Pecandu Narkotika Menurut Undang-Undang Nomor 35 Tahun 2009 Tentang Narkotika}

Tindak pidana narkotika merupakan tindak pidana khusus. Sebagaimana tindak pidana khusus, hakim diperbolehkan untuk menghukum dua pidana pokok sekaligus, pada umumnya hukuman badan dan pidana denda. Hukuman badan berupa pidana mati, pidana seumur hidup, atau pidana penjara. Tujuannya agar pemidanaan itu memberatkan pelakunya supaya kejahatan dapat ditanggulangi di masyarakat, karena tindak pidana narkotika sangat membahayakan kepentingan bangsa dan Negara. ${ }^{8}$

Semua zat yang termasuk golongan narkotika dapat menimbulkan ketagihan, yang dalam bahasa kedokteran disebut sebagai adiksi. Ketagihan yang terus menerus dan tidak dapat ditanggulangi lagi mengajibatkan ketergantungan (dependensi). ${ }^{9}$

Dadang Hawari menerangkan bahwa ketergantungan adalah kondisi yang kebanyakan diakibatkan oleh penyalahgunaan zat, yang disertai dengan sifat-sifat sebagai berikut:

1. zat yang dimaksud, dan kalau perlu dengan jalan apapun untuk Keinginan yang tak tertahankan (an over-powering desire ) terhadap memperolehnya;

2. Kecenderungan untuk menambah takaran (dosis) sesuai dengan toleransi tubuh;

3. Ketergantungan Psikologis, yaitu apabila pemakaian zat dihentikan akan menimbulkan gejala-gejala kejiwaan seperti kegelisahan, kecemasan, depresi dan sejenisnya;

4. Keterantungan fisik, yaitu apabila pemakaian zat dihentikan akan menimbulkan gejala fisik yang dinamakan gejala putus zat (withdrawal symptoms). ${ }^{10}$

Untuk Orang yang menggunakan Narkotika dalam keadaaan keter-gantungan secara fisik maupun psikis, dapat dikategorikan sebagai pecandu yang mempunyai legitimasi untuk mempergunakan narkotika demi kepentingan pelayanan kesehatan

\footnotetext{
7 Ruslan Renggong, Hukum Acara Pidana Memahami Perlindungan HAM dalam Proses Penahanan di Indonesia, (Prenada Media 2014).[224].

8 Gatot Supramono, op cit.[93]

9 Dadang Hawari, Penyalahgunaan dan Ketergantungan NAZA ( Narkotika, Alkohol, dan Zat Adiktif)( Gaya Baru 2003).[5].

10 ibid.[6].
} 
dirinya sendiri. Kategori seperti itu, dikarenakan penggunaan narkotika tersebut sesuai dengan makna dari Pasal 7 Undang-Undang Narkotika dan tentunya Pecandu yang dimaksud adalah seorang pecandu yang sedang menjalankan rehabilitasi medis khususnya dalam proses intervensi medis. Sehingga bila ada seorang Pecandu yang sedang menggunakan narkotika dalam kadar atau jumlah yang ditentukan dalam proses intervensi medis pada pelaksanaan rawat jalan, kemudian dia tertangkap tangan menggunakan narkotika untuk dirinya sendiri dan perkaranya diteruskan sampai tahap pemeriksaan di Pengadilan, maka sudah sepatutnya ia tidak terbukti bersalah menyalahgunakan narkotika dan jika Pecandu memang membutuhkan pengobatan dan/atau perawatan intensif berdasarkan program assesmen yang dilakukan oleh Tim Dokter/Ahli, maka berdasarkan Pasal 103 Ayat (1) huruf b Undang-Undang Narkotika, hakim di sini dapat menetapkan Pecandu yang tidak terbukti bersalah tersebut untuk direhabilitasi dalam jangka waktu yang bukan dihitung sebagai masa menjalani hukuman dan penentuan jangka waktu tersebut setelah mendengar keterangan ahli mengenai kondisi/taraf kecanduan Terdakwa.

Apabila orang yang menyalahgunakan narkotika dalam keadaan ketergantungan secara fisik maupun psikis, dapat dikategorikan sebagai pecandu yang tidak mempunyai legitimasi untuk mempergunakan narkotika demi kepentingan pelayanan kesehatannya. Pengkategorian seperti itu didasarkan pada pengertian Penyalahguna yang dimaksud pada Pasal 1 angka 15 Undang - Undang Narkotika, dimana ada unsur esensial yang melekat yaitu unsur tanpa hak atau melawan hukum. Mengenai penjabaran unsur tanpa hak atau melawan hukum telah dipaparkan penulis sebelumnya yaitu pada pokoknya seseorang yang menggunakan Narkotika melanggar aturan hukum sebagaimana dimaksud dalam Pasal 7 dan/atau Pasal 8 Undang-Undang Narkotika tersebut, maka pelaku tersebut tidak mempunyai hak atau perbuatannya bersifat melawan hukum.

Secara hukum penyalahguna dan pecandu Narkoba di satu sisi merupakan pelaku tindak pidana penyalahgunaan Narkoba, namun di sisi lain meraka merupakan korban. Pecandu Narkoba dianggap sebagai pelaku tindak pidana penyalahgunaan Narkoba adalah dengan adanya ketentuan undang-undang Narkoba yang mengatur 
mengenai pidana penjara yang diberikan kepada para pelaku penyalahgunaan Narkoba. Menurut Undang-Undang Narkoba, pecandu Narkoba tersebut merupakan korban, hal ini ditunjukkan dengan adanya ketentuan bahwa terhadap pecandu Narkoba dapat dijatuhi tindakan rehabilitasi.

Penyalahgunaan narkotika apabila diminta Visum Et Repertum akan berubah status menjadi pecandu dan hukumnya wajib direhabilitasi, penyalah-gunan pemula apabila terbukti dirayu, dibujuk, diperdaya, dan dipaksa menggunakan narkotika maka disebut sebagai korban penyalahgunaan narkotika dan hukumnya wajib direhabilitasi ( Pasal 54 Undang-Undang Narkotika). ${ }^{11}$

Penanggulangan terhadap tindak pidana narkotika dapat dilakukan dengan cara preventif, moralistik, abolisionistik dan juga kerjasama internasional. Penanggulangan secara preventif maksudnya usaha sebelum terjadinya tindak pidana narkotika, misalnya dalam keluarga, orang tua, sekolah, guru dengan memberikan penjelasan tentang bahaya narkotika. Selain itu juga dapat dengan cara mengobati korban, mengasingkan korban narkotika dalam masa pengobatan dan mengadakan pengawasan terhadap eks pecandu narkotika.

Definisi korban / victim menurut kamus Crime Dictionary sebagaimana dikutip Bambang Waluyo dalam bukunya, adalah orang yang telah mendapat penderitaan fisik atau penderitaan mental, kerugian harta benda atau mengakibatkan mati atas perbuatan atau usaha pelanggaran ringan dilakukan oleh pelaku tindak pidana dan lainnya. ${ }^{12}$ Dengan demikian dapat dikatakan bahwa yang dimaksud dengan korban adalah orang yang menderita kerugian fisik maupun mental sebagai akibat dari pelanggaran atau tindak pidana.

\section{Pertimbangan Hakim Dalam Memutus Pecandu Narkotika}

Seorang hakim dalam hal menjatuhkan pidana kepada terdakwa tidak boleh

\footnotetext{
${ }^{11}$ Anang Iskandar, Penegakan Hukum Narkotika (Rehabilitatif terhadap penyalahgunaan dan pecandu, represif terhadap pengedar) ( Elex Media Komputindo 2019).[51].

12 Bambang Waluyo, Victimologi, Perlindungan Saksi dan Korban, (Sinar Grafika 2011). [9].
} 
menjatuhkan pidana tersebut kecuali apabila dengan sekurang-kurangnya dua alat bukti yang sah, sehingga hakim memperoleh keyakinan bahwa suatu tindak pidana benar-benar terjadi dan terdakwalah yang bersalah melakukannya (Pasal 183 KUHAP). Alat bukti sah yang dimaksud adalah: (a). Keterangan Saksi; (b). Keterangan Ahli; (c). Surat; (d). Petunjuk; (e). Keterangan Terdakwa atau hal yang secara umum sudah diketahui sehingga tidak perlu dibuktikan (Pasal 184). ${ }^{13}$

\section{Contoh Kasus}

1. Putusan Perkara Nomor 592/Pid.Sus/2016/PN.Smg atas nama Terdakwa Yoyok Beny Koeswoyo;

2. Putusan Perkara Nomor 31/Pid.Sus/PN.TPG atas nama Terdakwa Reka Septi Hutagalung;

3. Putusan Perkara Nomor 51/PiD.Sus/2018/PN.POL atas nama Terdakwa Eko Budiono.

\section{Pertimbangan Hakim}

1. Putusan Perkara Nomor 592/Pid.Sus/2016/PN.Smg atas nama Terdakwa Yoyok Beny Koeswoyo

Adapun dasar pertimbangan hakim dalam menjelaskan putusan terhadap pelaku tindak pidana penyalahgunaaan narkotika meliputi :

Hal yang memberatkan, Perbuatan terdakwa bertentangan dengan program pemerintah didalam usaha memberantas peredaran clan penggunaan Narkotika secara ilegal. Hal-hal yang meringankan:

1. Terdakwa bersikap sopan di persidangan dan mengakui terns terang perbuatannya;

2. Terdakwa belum pernah dipidana;

3. Terdakwa menyesali perbuatannya.

13 Satjipto Rahardjo. Bunga Rampai Permasalahan Dalam Sistem Peradilan Pidana. (Pusat Pelayanan Keadilan dan Pengabdian Hukum 1998).[11]. 
2. Putusan Perkara Nomor 31/Pid.Sus/PN.TPG atas nama Terdakwa Reka Septi Hutagalung

Bahwa berdasarkan hal-hal yang memberatkan dan hal-hal yang meringankan sebagaimana telah dipertimbangkan di atas, dikaitkan juga dengan tujuan pemidanaan yang bukan semata-mata sebagai pembalasan atas perbuatan Para Terdakwa, namun diharapkan Para Terdakwa dapat menjadi anggota masyarakat yang baik di kemudian hari, maka Majelis Hakim memandang adil dan patut apabila Para Terdakwa dijatuhi hukuman sebagaimana yang akan disebutkan dalam amar putusan.

3. Putusan Perkara Nomor 51/PiD.Sus/2018/PN.POL atas nama Terdakwa Eko Budiono

Menimbang, bahwa berdasarkan hal-hal yang memberatkan dan hal-hal yang meringankan sebagaimana telah dipertimbangkan di atas, dikaitkan pula dengan tujuan pemidanaan yang bukan semata-mata sebagai pembalasan atas perbuatan Terdakwa, namun diharapkan Terdakwa dapat menjadi anggota masyarakat yang baik di kemudian hari, maka Majelis Hakim memandang adil dan patut apabila Terdakwa dijatuhi hukuman sebagaimana yang akan disebutkan dalam amar putusan

Dalam mengadili sebuah perkara hakim dapat mengacu pada ketentuanketentuanyang mengatur masalah jenis-jenis pidana, namun dalam menentukan jenis pidananya hakim harus melihat pada hasil pemeriksaan di sidang pengadilan dan mempertimbangakn faktor-faktor apa saja yang menjadikan terdakwa melakukan tindak pidana tersebut. Dalam Pasal 127 Undang-Undang Nomor 35 Tahun 2009 mengatur mengenai ketentuan pidana dan tindakan rehabilitasi bagi elaku penyalahgunaan Narkotika. Berdasarkan faktor-faktor dan alasan-alasan yang dikemukakan, tidak semua pelaku penyalahgunaan narkotika dapat dijatuhi dengan putusan tindakan rehabilitasi harus ada syarat-syarat dan klasifikasi tertentu yang diatur didalam Undang-Undang atau pun peraturan yang lainnya. Putusan hakim terhadap terdakwa tindak pidana penyalahgunaan Narkotika dijatuhkan berdasarkan pertimbangan yang sedail-adilnya sehingga tuntutan masyarakat akan tegaknya hukum dan keadilan dapat terpenuhi. 
Telah banyak pecandu Narkotika yang tertangkap lagi oleh aparat kepolisian setelah menjalani masa hukuman di penjara. Salah satu alasannya adalah tidak dapat lepas dari ketergantungan terhadap Narkotika dan terpaksa kembali menyalahgunakan Narkotika. Sehingga pemidanaan dengan pidana penjara tidaklah efektif untuk menjerakan pecandu Narkotika.Oleh karena itu, Rehabilitasi dianggap sebagai pemidanaan yang lebih tepat untuk menanggulangi penyalahgunaan Narkotika”. Ketentuan Hakim dalam menjatuhkan putusan tindakan Rehabilitasi bagi terdakwa Penyalahgunaan Narkotika terdapat dalam Pasal 54, Pasal 55 dan Pasal 103 Undang-Undang Nomor 35 tahun 2009 Tentang Narkotika.

\section{Kesimpulan}

Putusan hakim dalam perkara tindak pidana penyalahgunaan Narkotika tidak selalu sama, walaupun dengan kasus yang sama akan tetapi hasil putusan berbeda-beda inilah yang disebut sebagai putusan disparitas, di mana hakim memutus suatu perkara yang sama namun dengan hasil putusan yang berbeda. Perbedaan dalam pengambilan putusan tersebut disebabkan adanya beberapa faktor seperti faktor ekonomi, sosial serta fakta-fakta hukum yang terungkap dalam persidangan. Pecandu narkotika dapat dikatakan sebagai korban dari tindak pidana penyalahgunaan narkotika yang dilakukannya sendiri. Ratio Decidendi dalam putusan hakim terhadap penyalahguna Narkotika yaitu dalam memutuskan berat ringannya suatu pidana, hakim harus mempertimbangkan hal - hal seperti kesalahan pembuat, motif dan tujuan dilakukannya perbuatan tindak pidana, cara melakukan tindak pidana, sikap batin pembuat, riwayat hidup dan keadaan sosial ekonomi pembuat, sikap dan tindakan pembuat melakukan tindak pidana, pengaruh pidana terhadap masa depan pembuat, dan pandangan masyarakat terhadap tindak pidana yang dilakukan. 


\section{Daftar Bacaan}

\section{Buku}

Anang Iskandar, Penegakan Hukum Narkotika (Rehabilitatif terhadap penyalahgunaan dan pecandu, represif terhadap pengedar) (Elex Media Komputindo 2019).

Arief, Barda Nawawi,, Beberapa Aspek Kebijakan Penegakan dan Pengembangan Hukum Pidana (Citra Aditya Bakti 1998).

Bambang Waluyo, Victimologi, Perlindungan Saksi dan Korban (Sinar Grafika 2011).

Dadang Hawari, Penyalahgunaan dan Ketergantungan NAZA (Narkotika, Alkohol dan Zat Adiktif) (Gaya Baru 2003).

Gatot Supramono, Hukum Narkoba Indonesia (Djambatan 2004).

Mohammad Taufik Makarao, Suhasril, Risman F Sikumbank, Tindak Pidana Narkotika (Ghalia Indonesia 2003).

Muladi, Kapita Selekta Sistem Peradilan Pidana, (Badan Penerbit Universitas Diponegoro 1995).

Ruslan Renggong, Hukum Acara Pidana Memahami Perlindungan HAM dalam Proses Penahanan di Indonesia (Prenada Media 2014).

Satjipto Rahardjo. Bunga Rampai Permasalahan Dalam Sistem Peradilan Pidana. ( Pusat Pelayanan Keadilan dan Pengabdian Hukum 1998).

Sudarto, Kapita Selekta Hukum Pidana (Alumni 1986).

\section{Laman}

NN, 'Sinar edisi’ <www.HukumOnline.com >, accessed 8 September 2011. 